CORRIGENDUM

doi:10.1038/nature07941

\title{
ABIN-1 is a ubiquitin sensor that restricts cell death and sustains embryonic development
}

Shigeru Oshima, Emre E. Turer, Joseph A. Callahan, Sophia Chai, Rommel Advincula, Julio Barrera, Nataliya Shifrin, Bettina Lee, T. S. Benedict Yen, Tammy Woo, Barbara A. Malynn \& Averil Ma

Nature 457, 906-909 (2009)

In this Letter, the name of T. S. Benedict Yen was incorrectly listed as Benjamin Yen. This author is affiliated with the Pathology Service, VA Medical Center, and the Department of Pathology, University of California, and not with the Department of Medicine, University of California, as originally listed. 